\title{
Has biodiversity fallen off the development agenda? A case study of the UK Department for International Development
}

Dilys RoE

\begin{abstract}
Since the early 2000 s increasing attention has been paid to the relationship between biodiversity conservation and poverty reduction and a debate has ensued over various aspects of this relationship. One element of this debate has been concerned with an apparent lack of attention to biodiversity conservation on the international development agenda following the prioritization of poverty reduction. This paper explores whether this lack of attention is real or perceived by reviewing changes in biodiversity policy within the UK Department for International Development (DFID). It is clear that attention to biodiversity within DFID policy has changed significantly over time. There was strong support for wildlife conservation until the 1990s, including technical assistance, funding for integrated conservation and development projects (ICDPs), and community-based conservation. By the 200os, however, the main focus had switched from funding wildlife conservation to mainstreaming biodiversity concerns into development policy. The degree to which the explicit focus on poverty reduction that emerged in the late 1990s drove this change is debatable. Changes in aid architecture, UK politics and clearer differentiations between the roles of DFID and the Department for Environment, Food and Rural Affairs (DEFRA) in addressing biodiversity concerns have also shaped DFID's policy. Meanwhile, the political traction afforded to climate change demonstrates that it is possible for environmental issues to sit alongside poverty reduction in international development policy. However, communicating the societal implications of biodiversity loss has proved to be more challenging than for climate change. Better understanding of the mechanisms by which development assistance is disbursed would help the conservation community identify key opportunities for engagement.
\end{abstract}

Keywords Aid, biodiversity, international development, poverty, UK policy

DiLys Roe IIED, 80-86 Gray's Inn Road, London, WC1X 8NH, UK E-mail dilys.roe@iied.org

Received 21 December 2011. Revision requested 27 February 2012.

Accepted 28 March 2012.

\section{Introduction: biodiversity, poverty and international development policy}

Since the early 2000 s increasing attention has been paid $\checkmark$ to the relationship between biodiversity conservation and poverty reduction and a debate has ensued over various aspects of this relationship. The debate is multifaceted and different elements of it have been in play for over 50 years (see Roe, 2008 for a description of the origins and evolution of the debate). Recently, one element of this debate has been concerned with an apparent lack of attention to biodiversity conservation on the international development agenda following the prioritization of poverty reduction and the emphasis on achieving the Millennium Development Goals.

Poverty reduction has been a recurring theme on the international development agenda (Maxwell, 1999; Killick, 2005; Fukudu-Parr \& Hulme, 2009) and became the dominant focus of development assistance policy in the late 1990s. In 1996 the Development Assistance Committee of the Organization for Economic Cooperation and Development (OECD) published a set of seven povertyfocused International Development Targets (OECD, 1996) and many development assistance agencies responded by shifting their policies in line with these targets. In 2000 the UN repackaged the Targets as the Millennium Development Goals, resulting in an even greater alignment of bilateral agency policy and an unprecedented level of international commitment to poverty reduction (Satterthwaite, 2003; Fukudu-Parr \& Hulme, 2009).

In parallel with this shift in development policy there was also a shift in the modalities of aid delivery. The World Bank and International Monetary Fund initiated the development of country-level Poverty Reduction Strategy Papers underpinned by the Comprehensive Development Framework that emphasized developing country ownership and direction of the development agenda (Stiglitz, 1998). This influenced the delivery of development assistance funds and the choice of aid instruments employed, with an emphasis on direct budget support rather than externallyimplemented projects as the preferred (although by no means only) mechanism (Warrener, 2004).

This dual shift in aid policy and process had implications both for the priority afforded to biodiversity conservation by development assistance agencies and for the ability of conservation agencies to access development assistance 
funding (Lapham \& Livermore, 2003; Roe \& Elliott, 2004). In the early 2000 s one reaction to this was a voicing of concern that biodiversity had fallen off the development agenda (IISD, 2003; Sanderson \& Redford, 2003; Sanderson, 2005; Phillips \& Vaughan, 2006), although Lapham \& Livermore (2003) noted that it was not so much biodiversity but rather conservation that had fallen by the wayside. I explore this issue through a review of the fate of biodiversity concerns within the UK Department for International Development (DFID). DFID only came into being in 1987; its predecessors included the Overseas Development Administration, the Overseas Development Ministry and the Department of Technical Cooperation. However, to avoid confusion the title DFID is used throughout this paper to refer to all these bodies. DFID is an interesting case study because it is considered a leader in good practice amongst the development assistance community (EAC, 2006). It also contributed to the conservation-poverty debate of the early 2000 s when the UK Minister for International Development highlighted the so-called bushmeat crisis in terms of its implications for the livelihoods of poor peoples (Short, 2002). Table 1 summarizes DFID's changing approach to biodiversity over time according to statements recorded in Hansard, the official record of UK parliamentary questions and debates.

\section{Approach and methods}

This case study addresses the following questions: To what degree was biodiversity a priority for DFID prior to the 1992 Rio Earth Summit and the coming into force of the Convention on Biological Diversity (CBD)? Did the 1997 shift in focus to poverty reduction precipitate a change in attention afforded to biodiversity conservation? What has happened since 2002 when the so-called poverty prerogative was confirmed by the UK International Development Act and the World Summit on Sustainable Development?

One way to answer these questions would have been to analyse expenditure on biodiversity over time. However this is not straightforward. The OECD Development Assistance Committee collects data on the aid expenditure of its members and these data have been the source of a number of analyses of biodiversity-related aid flows (e.g. Lapham \& Livermore, 2003; CBD, 2007; OECD, 2008) but the data are notoriously unreliable because of the non-standardized way by which different agencies code their financial transactions (Lapham \& Livermore, 2003; Miller et al., 2010). A new database (AidData) has recently been developed to incorporate a wider range of data sources but again the data are not coded specifically for biodiversity (D.C. Miller \& J.T. Roberts, pers. comm.). DFID's (now discontinued) Natural Resources Information System (DFID, undated) includes archive information on biodiversity project spending but this is incomplete and is not disaggregated on an annual basis.
In the absence of reliable financial information I constructed a policy timeline using several methods. I searched the National Archive website, and DFID website and web archive for key policy documents and annual reports and reviewed web-based literature to identify relevant documents (e.g. evaluation reports) that provide a snapshot of DFID at specific points in time. I also searched the archives of Hansard (transcripts of UK parliamentary debates) for details of written questions and answers relevant to DFID's activities and policies on biodiversity. Key informant interviews were conducted with DFID's environment staff (past and current) to check the accuracy and interpretation of the material collected and to fill key gaps in the timeline and trends analysis. Resulting from this research, the following sections describe the status of biodiversity in DFID policy in each of the key periods in DFID's history.

\section{Biodiversity and poverty in early development assistance policy: 1961-1987}

In the early years of development assistance it was common for bilateral aid funds to be focused on institutional support to government departments in former colonies. In the context of biodiversity this meant that the aid programme supported wildlife and forestry department staff (Sayers \& Wells, 2004). There was also an emphasis on training. In 1963, for example, the UK Government was one of the donors that established the College of African Wildlife Management in Mweka, Tanzania (Adams \& McShane, 1992). In addition to this institutional support and capacity building focus, the late 1970 s and early 1980 s were a period of concern about fuelwood shortages and desertification, which resulted in investment in tree planting projects (ODI, 2003).

The World Conservation Strategy (IUCN et al., 1980) and the subsequent development of National Conservation Strategies as frameworks for integrating environmental concerns into development processes stimulated a closer engagement between conservation organizations and development assistance agencies. Oates (1999) suggests this engagement was also associated with the increasing scale and ambitions of conservation organizations and hence their escalating dependence on sources of more substantial funds. Regardless of the motivation, this period coincided with a shift in the delivery of development aid beyond institutional support to more targeted projects. DFID established a joint funding scheme as a mechanism for cofinancing projects with NGOs. WWF-UK was one of the few conservation NGOs to benefit from the joint funding scheme and through this DFID started to support a number of projects aimed at 'conservation through development'. Examples of such projects included those in the Korup 
TABLE 1 Comments from the Department for International Development (DFID) representatives reflecting the changing approach to biodiversity within DFID, 1988-2009. Source: Hansard archives (UK Parliament, undated a,b).

\begin{tabular}{|c|c|}
\hline Year & Comment \\
\hline Jan. 1988 & $\begin{array}{l}\text { The Overseas Development Administration is in contact with Rhino Rescue about the possibility of co-funding a project } \\
\text { in Kenya, the principal aim of which is the preservation of the black rhino population. }\end{array}$ \\
\hline Nov. 1989 & $\begin{array}{l}\text { We [DFID] have been providing help to the Kenya wildlife department for many years, and expect to continue to do so. } \\
\text { We shall look at all the ways in which we can reasonably help with conservation. }\end{array}$ \\
\hline Nov. 1989 & $\begin{array}{l}\text { We [DFID] are already funding a number of wildlife conservation activities in Africa, and are always ready to consider } \\
\text { new requests for help. }\end{array}$ \\
\hline Mar. 1993 & $\begin{array}{l}\text { My Department [Environment] works closely with the Overseas Development Administration, through which major } \\
\text { financial support for conservation overseas is given. }\end{array}$ \\
\hline June 1997 & $\begin{array}{l}\text { DFID provides support to departments in several developing countries, responsible for wildlife, forests and } \\
\text { conservation, and for community-based development programmes, to help them and the communities they serve } \\
\text { better manage and benefit from their wildlife resources. }\end{array}$ \\
\hline Dec. 1997 & $\begin{array}{l}\text { DFID is committed to providing continued assistance to help poor people in developing countries benefit from } \\
\text { safeguarding biodiversity. }\end{array}$ \\
\hline Mar. 1999 & $\begin{array}{l}\text { Our [DFID] objective is to ensure that this important issue [loss of biodiversity among traditional crop varieties] is } \\
\text { taken fully into account in all relevant aspects of the UK's international policies. }\end{array}$ \\
\hline Mar. 1999 & $\begin{array}{l}\text { Our [DFID] aim is to ensure that degradation of the forests is reversed and that poor people who live in and around the } \\
\text { forests derive more benefits from the way they are managed. This will give wildlife dependent on the forest, including } \\
\text { orang-utans, a better chance of survival. }\end{array}$ \\
\hline Feb. 2001 & $\begin{array}{l}\text { Our [DFID] primary aim is poverty reduction. We are not directly involved in ape protection projects. The sustainable } \\
\text { management of ecosystems is important in improving poor peoples' livelihood and in some cases contributes to the } \\
\text { conservation of apes and their habitats, principally through support for sustainable forest management. }\end{array}$ \\
\hline Feb. 2001 & $\begin{array}{l}\text { Forests play a major role in providing livelihoods for poor people, and this is the starting point for our [DFID] } \\
\text { involvement in the sector. }\end{array}$ \\
\hline July 2001 & $\begin{array}{l}\text { DFID's purpose is poverty eradication, not conservation. DFID supports the sustainable management of wild animal } \\
\text { populations where it is key to improving poor peoples' livelihood opportunities, for example through improved forest } \\
\text { management and community wildlife initiatives. }\end{array}$ \\
\hline Apr. 2002 & $\begin{array}{l}\text { DFID is concerned with reducing poverty. We fund and will continue to fund projects and studies that address } \\
\text { sustainable forest management and bushmeat production where this is key to tackling poverty. }\end{array}$ \\
\hline May 2002 & $\begin{array}{l}\text { The Department for International Development (DFID), while primarily concerned with helping to eradicate world } \\
\text { poverty, also recognizes the need to address concerns about the pressures on endangered species of the bushmeat trade. } \\
\text { DFID's concern about bushmeat is focused on the impact of the hunting, selling and consumption of bushmeat on the } \\
\text { food security and livelihoods of poor people. }\end{array}$ \\
\hline Apr. 2004 & $\begin{array}{l}\text { DFID is committed to working with governments ... to strengthen their capacity to deal with wildlife and poverty issues. } \\
\text { We do this by supporting sector reform. It is for the governments concerned to prioritize actions within their sector } \\
\text { reform programmes. }\end{array}$ \\
\hline Apr. 2004 & $\begin{array}{l}\text { DFID has a two-pronged strategy for ensuring that biodiversity is integrated into development policy and practice by: } \\
\text { supporting partner governments to identify links between biodiversity and poverty and integrate environmental } \\
\text { matters, including biodiversity, into their national policy frameworks for poverty reduction (DFID includes } \\
\text { biodiversity in its screening processes for bilateral programmes); and promoting the adoption of strategic } \\
\text { environmental assessments in the multilateral agencies DFID supports, the EC, the UN, the development banks and } \\
\text { others. }\end{array}$ \\
\hline July 2006 & $\begin{array}{l}\text { DFID is committed to incorporating biodiversity into development in helping to improve poor people's livelihoods and } \\
\text { in supporting developing countries to use the benefits of biodiversity and conservation to reduce poverty. }\end{array}$ \\
\hline Oct. 2007 & $\begin{array}{l}\text { DFID's priority, as expressed in the International Development Act, is the reduction of poverty. Any DFID engagement } \\
\text { in overseas conservation must therefore deliver direct and tangible benefits to the poor. }\end{array}$ \\
\hline Jan. 2009 & $\begin{array}{l}\text { DFID recognizes the importance of biodiversity conservation to its poverty reduction efforts and continues to channel } \\
\text { significant financial support to the sector through a range of mechanisms. }\end{array}$ \\
\hline
\end{tabular}

National Park in Cameroon and the Cross River National Park in Nigeria (Oates, 1999).

This period also coincided with escalating global concern about the rate and scale of tropical deforestation. In 1985 the Tropical Forestry Action Plan was initiated by the Food and Agriculture Organization of the UN, and other international agencies, as a means for coordinating donor support for forest management and conservation (Oksanen et al., 1993). In addition to its support for integrated conservation and development programmes DFID also invested significant funding in forest conservation in response to the national level plans that the Tropical Forestry Action Plan stimulated. 


\section{The sustainable development decade: 1987-1997}

By 1987 increasing public awareness of global environmental problems, including biodiversity loss, deforestation, desertification and climate change, had attracted political attention. DFID responded to the increasing international and domestic concern in three main ways (Flint et al., 2000): (1) environment was accorded a high policy priority with publication of its first statement on the environment (Hansard, 1987) and later declaring it central to the UK aid programme (NAO, 1992), (2) it ensured environmental issues were addressed in the design of its development interventions through the introduction of an environmental appraisal system (ODA, 1989), and (3) it sought to increase its financial contribution to environmental issues. By the end of 1990 it was funding 33 biodiversity conservation projects, either via the joint funding scheme or through its bilateral programmes, at an estimated cost of GBP 7.2 million (Bennett, 1991).

In 1990 DFID initiated a review of its role in promoting biodiversity conservation. The report of the findings (Flint, 1991) included a comment from the Minister for Overseas Development recognizing the role of development assistance agencies in supporting biodiversity conservation: 'Most of the world's biological diversity is found in developing countries and aid agencies such as the [Overseas Development Administration] have a role to play in helping those countries conserve and develop it for present and future generations' (p. 4). Subsequently, following the 1992 Earth Summit, the Prime Minister announced extra emphasis on five areas of the British aid programme: biodiversity, energy, forestry, population and agriculture (Flint et al., 2000).

In 1993 DFID started to develop a Wildlife Strategy for Africa to guide future support in a more strategic manner (IIED, 1994). At this time there was increasing attention within the development community to participatory approaches to development and to the concept of sustainable rural livelihoods (Chambers \& Conway, 1992). DFID noted synergies with the parallel conservation paradigm of community-based natural resource management and commissioned a review of such approaches (IIED, 1994). DFID subsequently convened a consultation meeting on African wildlife policy at which it described its approach as 'to improve the livelihoods of the rural poor through the sustainable use and management of wildlife resources and their habitats' (ODA, 1996, p. 9) and announced that its conservation commitments had increased to $>$ GBP 23 million since the Earth Summit.

\section{The refocusing of UK aid on poverty: 1997-2002}

In the mid 199os there was increasing recognition that the structural adjustment programmes that had dominated international development assistance in the 1980 s and early 1990s were not working (Killick, 2005). This contributed to a major rethink of aid priorities and modalities amongst OECD donor agencies and a clear policy move towards a greater focus on poverty reduction (OECD, 1996). DFID responded to this international policy shift with a White Paper on international development (DFID, 1997), which stated specifically that UK development assistance would be refocused towards poverty elimination. At the same time, however, it retained an emphasis on environment and a commitment to biodiversity conservation: 'We shall continue to help poor people in developing countries, often rich in species and habitats, but lacking resources, to manage and benefit from their biodiversity' (p. 52).

Alongside the White Paper DFID published a number of sectoral policy statements making the link between the White Paper and different areas of policy interest. One of these was Biodiversity Matters (DFID, 1998) which highlighted three priority issues: (1) improving poor people's livelihoods through sustainable use and conservation of biodiversity, (2) protecting those livelihoods by preventing biodiversity loss that can increase vulnerability and have disproportionate effects on the poor, and (3) providing alternatives for people who are otherwise forced to overexploit biological resources.

DFID also initiated the Linking Policy and Practice in Biodiversity project, which was intended to explore how to improve integration of biodiversity into its goal of poverty reduction. DFID was the first donor agency to investigate explicitly the linkages between biodiversity and poverty agendas and it viewed this as cutting-edge work (informant interview; Short, 2003). Based on the findings of the study (Koziell, 2001; Koziell \& Saunders, 2001) a new policy statement was produced (DFID, 2001) that stated 'DFID is committed to making biodiversity work for the poor' and that highlighted three major areas of intervention: (1) influencing policies and institutions to integrate environmental concerns (including biodiversity) into development planning, (2) strengthening civil society and engaging the private sector for pro-poor interventions and management of biodiversity, and (3) supporting research to improve understanding of the role of natural diversity in the lives of the poor. DFID also funded a study in collaboration with IUCN and the EC on biodiversity and development, which identified a number of guiding principles for biodiversity in development cooperation (Biodiversity in Development Project, 2001).

While this all sounds positive, there was some internal disquiet. One key informant noted that in some ways the CBD itself was a hindrance to integrating biodiversity into DFID's agenda because of its focus on national sovereignty rather than biodiversity as a global public good, and a second key informant noted that the breadth of specialized issues addressed by the CBD further served to make biodiversity appear as a distraction from the DFID 
mainstream. DFID was also questioning its investment in conservation projects. Biodiversity Matters (DFID, 1998) had proudly announced: 'since 1992, DFID has spent over GBP 170 million on more than 150 projects with a biodiversity focus in over 40 countries'. Meanwhile, a second White Paper (DFID, 2000a) highlighted the need for reducing support for stand-alone projects and increasing direct budget support and sector-wide reforms. The Wildlife and Poverty Study (DFID, 2002) highlighted a significant decline in wildlife projects, some of which had been longrunning, with no further projects in the pipeline (Table 2). The study provided various explanations for the decline including: growing cynicism as to the effectiveness of integrated conservation and development initiatives; a state of flux in DFID's overall rural development strategy; a change in aid instruments away from field projects; a sense that wildlife projects were geographically constrained in scope and non-replicable, hence having high transaction costs; and ongoing concerns about the negative impact of conservation on poor people. Following this study, the Secretary of State Hilary Benn commented: 'No new funding has been released specifically to improve wildlife management since its publication' (Hansard, 2004).

The period of refocusing on poverty culminated with a new International Development Act, which came into force in the UK in 2002. This Act requires two conditions to be met in the provision of any development assistance: (1) that it will contribute to poverty reduction, and (2) that its purpose is to further sustainable development (National Archives, 2004). The Act's definition of 'sustainable development' is not, however, consistent with common international understandings of the concept and caused considerable concern, to conservation organizations and others, about its failure to balance social and economic priorities with environmental concerns (EAC, 2006).

In the same year the World Summit on Sustainable Development highlighted poverty reduction as the overarching priority for sustainable development (United Nations, 2002a). Although biodiversity was one of five priority issues addressed at the Summit, the conservation of biodiversity is set in the context of achieving poverty reduction objectives. The Plan of Implementation of the World Summit on Sustainable Development states that reversing the trend in biodiversity loss will only be achieved if local people benefit from the conservation and sustainable use of biological diversity (United Nations, 2002b).

\section{Abdicating responsibility for biodiversity - or joined-up government? 2002-present}

By 2005 DFID was making it clear that responsibility for international biodiversity lay with the Department for Environment, Food and Rural Affairs (DEFRA; Hansard, 2005; EAC, 2007). Following the World Summit on Sustainable Development DFID had taken on responsibility for ensuring the integration of biodiversity concerns into development assistance policy but only as part of a wider World Summit on Sustainable Development Delivery Plan for international biodiversity coordinated by DEFRA (DEFRA, 2006). That one Department should lead on a policy area such as biodiversity and another contribute to a broader work plan was normal practice and reflected the specific Public Service Agreements by which each Department was bound. These were a product of a 1997 Comprehensive Spending Review which highlighted crossdepartmental synergies and joint working opportunities. The Public Service Agreements detailed the exact outcomes each department would deliver with the money provided (HM Treasury, 2000). From the start DEFRA's Public Service Agreements have included objectives on international environmental protection and sustainable development whereas DFID's have been more focused on delivery of the Millennium Development Goals.

Nevertheless DFID continued to support major programmes that supported biodiversity conservation, although they were not necessarily labelled as such. Examples include its work on illegal fishing and its work to address forest governance and illegal logging (informant interview). For example, DFID was an early contributor to

TABLE 2 Examples of wildlife projects supported by DFID in 2002. Sources: Hansard (2001), DFID (2002).

\begin{tabular}{lll}
\hline Project & Country & Period of support \\
\hline Wildlife Intensification for Livelihood Development & Namibia & $1999-2002$ \\
Mount Cameroon & Cameroon & $1984-2002$ \\
Ruaha Ecosystem Wildlife Management Project/Mbomipa & Tanzania & $1992-1996$ \\
Community Wildlife Project & & $1997-2001$ \\
Madikwe Community Wildlife Management & South Africa & $1997-2001$ \\
Cross River State Community Forestry & Nigeria & $1996-2001$ \\
Gashaka Gumpti/Kupe & Nigeria/Cameroon & $1991-2001$ \\
Kunene/Caprivi & Namibia & $1991-2001$ \\
Coastal forests/Bogoria/Udzungwa & Kenya/Tanzania & $1991-2001$ \\
Mamiraua & Brazil & $1991-2000$ \\
\hline
\end{tabular}


the Congo Basin Forest Fund, the objectives of which are to promote conservation, livelihoods and civil society participation (African Development Bank, 2008). In other cases conservation organizations were able to access alternative DFID funding schemes by stressing different objectives in their work. The Civil Society Challenge Fund, for example, was a source of funding for conservation work that included building the capacity of local institutions and it benefited organizations such as BirdLife International, Fauna \& Flora International and the Royal Society for the Protection of Birds (DFID, 2012), while the Programme Partnership Agreement scheme benefited a number of NGOs including WWF-UK (DFID 2011a).

Furthermore, DFID continued to participate in an interdepartmental ministerial group on biodiversity, which was established in 2004 to ensure coordination between DFID, DEFRA and the Foreign and Commonwealth Office on international biodiversity activities (Smith et al., 2008). The group met on several occasions between 2004 and 2009 to discuss a coordinated response to specific issues, including bushmeat, biodiversity in the UK Overseas Territories, and how best to deploy efforts on international biodiversity conservation given the government's wide range of international commitments but limited resources. By 2010, however, the Group had been disbanded and reconvened as the Inter-Departmental Group on Biodiversity in the Overseas Territories, this being the key common area of interest between DFID, DEFRA and the Foreign and Commonwealth Office (DEFRA, 2010).

Most recently, the current economic downturn and the associated changes to departmental budgets have resulted in increased DFID-DEFRA collaboration on biodiversity, and a partial return to funding conservation projects. DEFRA has run a funding scheme for biodiversity projects (the Darwin Initiative) since 1992. Following the cuts to DEFRA's budget in 2010, DFID (whose budget was ringfenced) has co-funded the Initiative and will provide the bulk of funding from 2012 onwards. As a result new projects will have to meet additional poverty-related criteria (informant interview).

\section{Climate change - the only environmental ill? 2004-present}

By 2004 UK NGOs had started to criticize the loss of attention to biodiversity within DFID (BOND, 2004). DFID's response was to highlight a redefinition of its role in meeting the UK's obligations on international biodiversity conservation, whereby support to biodiversity centred around its contributions to the Global Environment Facility, to which the UK was, and remains, a major donor (informant interviews). In 2005 the UK used its then presidency of the G8 to push for climate change as a key priority (informant interview). Subsequently concerns continued to escalate over
DFID's attention to climate change above any other environmental issues (EAC, 2006) and its downgrading of expertise and capacity on wider environmental protection issues, including biodiversity (NAO, 2010).

DFID's own perspective, however, was that their engagement on other environmental issues had been consistent but that their focus on climate change had increased significantly (NAO, 2010). It could be argued that the political traction associated with climate change has actually helped elevate environmental issues within DFID in the latter part of the 2000s, balancing a period in the mid 20oos when DFID had focused on growth and economics (informant interview).

Following the election of the new coalition government in 2010, and as part of its public spending cuts programme, DFID undertook a detailed review of its activities and announced a new approach to UK aid (DFID, 2011b), with a stronger focus on results, value for money and poor countries. Tackling climate change remains a core element of the strategy, which is still strongly rooted in the Millennium Development Goals. Biodiversity is not mentioned specifically although there is a commitment to protect forests, not just on the basis of their contribution to reducing carbon emissions but also because of the role they play in supporting poor people's livelihoods.

\section{Conclusions: poverty, politics or personalities?}

It is clear from this review that attention to biodiversity within DFID policy has changed significantly over time. However, the degree to which biodiversity has fallen off the development agenda and changes in biodiversity policy have been driven by a refocusing of international development policy on poverty reduction are debatable for a number of reasons.

Firstly, the term biodiversity is multifaceted and DFID has paid different levels of attention to different elements of biodiversity (e.g. wildlife, crop genetic resources, forests). Criticism of the lack of attention to biodiversity within development policy has largely come from those conservation organizations that are predominantly concerned with wildlife rather than with biodiversity in its broadest sense. Without doubt, DFID's attention to wildlife has decreased dramatically and all but ceased by the early 2000 . Nevertheless, DFID has continued to maintain broad attention to biodiversity with its more recent focus on integrating biodiversity concerns into development policy (termed 'biodiversity mainstreaming') and with its longstanding investment in forestry and natural resource governance.

Secondly, in some cases investment in biodiversity projects ceased prior to the policy switch towards international poverty reduction. In Kenya, for example, DFID had provided support to the Indigenous Forest Conservation 
Project, which ceased in 1994, and to the Kenya Wildlife Service through the Protected Area and Wildlife Services Interim Support Project, which ended in 1999. In both cases the lack of commitment by government partners was cited as a major driver for the end of support (ITAD, 2001).

Thirdly, although poverty became the overriding aim of DFID policy from 1997 onwards, it was not absent from earlier policy discussions when support for wildlife and biodiversity conservation was high. In 1975 the new Labour government published a White Paper (ODI, 1975) that specified that aid should be allocated so as to have 'the most effect in alleviating the worst poverty over the long term'. Similarly, in 1995 DFID undertook a Fundamental Expenditure Review which emphasized the need to target its efforts more effectively to meet its overarching objective of poverty reduction and sustainable development (Hansard, 1996).

Finally, the emphasis on poverty did not automatically imply a lack of emphasis on biodiversity. The period 1997-2000 appears to demonstrate a huge commitment to biodiversity. Nevertheless, it is difficult from a review of policies and public statements to determine the real value accorded to biodiversity within DFID. An evaluation of DFID's environmental activities carried out in the late 1990s concluded that despite the central importance attached to the conservation and sustainable management of the environment in the 1997 White Paper biodiversity had become 'the forgotten cornerstone of sustainable development' (Flint et al., 2000). During the Environmental Audit Committee inquiry in 2006 evidence from WWF-UK highlighted a similar failure to translate good policy into action: 'References to the environment are often cursory and demonstrate either a lack of understanding or an unwillingness to incorporate across the board what is-in theory at least-DFID policy' (EAC, 2006, p. 29).

Overall, it can be argued that changes in DFID biodiversity policy can be aligned with changes in UK politics as much as they can with refocusing on poverty. Other development agencies that are committed to poverty reduction and achieving the Millennium Development Goals have maintained much clearer public commitments to biodiversity than DFID. In particular, Austria, France, Germany and the USA have a specific policy on biodiversity (Roe, 2010). USAID stands out from other agencies in that its focus on biodiversity remains aligned with the traditional activities of the major conservation organizations (USAID, 2005). In the UK, however, the shift in international thinking about development coincided with a change in government and in the political status of DFID. The new DFID Minister, Clare Short, had significant personal impacts on UK development policy in the late 1990s and early 2000s (Killick, 2005), which included a distancing from NGOs (Vereker, 2002; Barder, 2005). Furthermore, the Comprehensive Spending Review and associated public service agreements as well as the International Development
Act enforced far greater public accountability, clarity of purpose and attention to more coordinated policy across different government departments (so-called joined-up government) than previously.

The political attention afforded to climate change shows clearly that it is possible for environmental issues to sit alongside poverty concerns within development policy. Biodiversity conservation and poverty alleviation need to be equally well communicated as linked agendas (Sachs et al., 2009). Efforts such as the study on The Economics of Ecosystems and Biodiversity (TEEB, 2010) have started to make a difference and the DFID multi-million pound research programme on Ecosystem Services and Poverty Alleviation, as well as its support to the World Bank initiative on Wealth Accounting and Valuation of Ecosystem Services and to the nascent Intergovernmental Panel on Biodiversity and Ecosystem Services are evidence of its continued interest (informant interview). Beyond better communications, the conservation community also needs to keep up with the politics of development and to improve its understanding of the way the aid system functions if it is to find the most effective ways to channel development funding to biodiversity concerns. In this socalled age of austerity this means making convincing arguments that investing in biodiversity is value for money. It also requires working with partners in developing countries, including civil society organizations, parliamentarians and policy makers, to ensure biodiversity is prioritized at the national level rather than by trying to fit old-style conservation projects into the new aid architecture.

\section{Acknowledgements}

Preparation of this review would not have been possible without the insights and inputs of a number of DFID staff, past and present, to whom grateful thanks are due: Steve Bass, former Chief Environment Advisor; Andrew Bennett, former Chief Natural Resources Advisor; Mark Eckstein, former Environment Advisor; Joanna Elliott, former Consultant Wildlife Advisor; Izabella Koziell, current Climate and Environment Advisor.

\section{References}

Adams, J.S. \& McShane, T.O. (1992) The Myth of Wild Africa: Conservation Without Illusion. W.W. Norton, New York, USA. African Development Bank (2008) Framework Document for the Establishment of the Congo Basin Forest Fund (CBFF). Http://cbffund.org/sites/default/files/Framework_Document_\%2ofor_ the_Establishment_of_the_Congo_Basin_Forest_Fund.pdf [accessed 13 December 2011].

BARder, O. (2005) Reforming Development Assistance: Lessons from the UK Experience. Working Paper Number 70. Center for Global Development, Washington, DC, USA. 
Bennett, A. (1991) Introduction. In Biological Diversity and Developing Countries: Issues and Options (ed. M. Flint), pp. 1-8. Overseas Development Administration, London, UK.

Biodiversity in Development Project (2001) Strategic Approach for Integrating Biodiversity in Development Cooperation. European Commission, Brussels, Belgium/IUCN, Gland, Switzerland, and Cambridge, UK.

BOND (British Overseas NGOs in Development) (2004) BOND-DEG notes for DEFRA/DFID Meeting on International Environment and Development Agendas. Internal Memo, BOND Development and Environment Group.

CBD (Convention on Biological Diversity) (2007) Review of Implementation of Articles 20 and 21. Report of the $\mathrm{Ad}$ Hoc Open-ended Working Group on Review of Implementation of the Convention. Second Meeting, UNESCO, Paris 9-13 July 2007. Http://www.cbd.int/wgri2/doc/ [accessed 29 February 2012].

Chambers, R. \& Conway, G. (1992) Sustainable Rural Livelihoods: Practical Concepts for the 21st Century. Institute for Development Studies, Brighton, UK.

DeFra (Department for Environment, Food and Rural Affairs) (2006) Beyond Johannesburg: Delivering Our International Biodiversity Commitments (updated July 2006). Http://archive.defra.gov.uk/sustainable/government/ international/documents/biodiversity-2006.pdf [accessed 31 October 2011].

DeFra (Department for Environment, Food and Rural AfFAIRS) (2010) Note of IDGBOT meeting 2. Http://archive.defra. gov.uk/environment/biodiversity/documents/otbg-meeting.pdf [accessed 31 October 2011].

DFid (Department for International Development) (undated) Natural Resources Information System. Http://www. narsis.org [accessed 1 October 2012].

DFid (Department for International Development) (1997) Eliminating World Poverty: A Challenge for the 21st Century. White Paper on International Development. Her Majesty's Stationery Office, Norwich, UK.

DFid (Department for International Development) (1998) Biodiversity Matters. Department for International Development, London, UK.

DFid (Department for International Development) (2000) Eliminating World Poverty: Making Globalization Work for the Poor. White Paper on International Development. Her Majesty's Stationery Office, Norwich, UK.

DFid (Department for International Development) (2001) Biodiversity: A Crucial Issue for the World's Poorest. Department for International Development, London, UK.

DFid (Department for International Development) (2002) Wildlife and Poverty Study. Department for International Development, London, UK.

DFid (Department for International Development) (2011a) WWF-UK Programme Partnership Agreement. Http://www.dfid. gov.uk/work-with-us/funding-opportunities/not-for-profitorganisations/ppas/wwf/ [accessed 5 March 2012].

DFid (Department for International Development) (2011b) UK Aid: Changing Lives, Delivering Results. Department for International Development, London, UK.

DFid (Department for International Development) (2012) Civil Society Challenge Fund. Http://www.dfid.gov.uk/Work-withus/Funding-opportunities/Not-for-profit-organisations/CSCF/ [accessed 5 March 2012].

EAC (Environmental Audit Committee) (2006) Trade, Development and Environment: The Role of DFID. The Stationery Office, London, UK.
EAC (Environmental Audit Committee) (2007) Government Response to the Committee's Tenth Report of Session 2005-06: Trade, Development and Environment-the Role of DFID. The Stationery Office, London, UK.

Flint, M. (1991) Biological Diversity and Developing Countries: Issues and Options. Overseas Development Administration, London, UK.

Flint, M., Balogun, P., Gordon, A., Hoare, R., Smith, D., Voysey, B. \& Ziegler, A. (200o) Environment: Mainstreamed or Sidelined? Environmental Evaluation Synthesis Study Main Report, Volume 1. Department for International Development, London, UK.

FuKUdu-PARR, S. \& Hulme, D. (2009) International Norm Dynamics and the 'End of Poverty': Understanding the Millennium Development Goals. Brooks World Poverty Institute Working Paper 96. University of Manchester, Manchester, UK.

Hansard (1987) Environmental Protection. House of Lords Debate, 13th May 1987. Http://hansard.millbanksystems.com/lords/1987/ may/13/environmental-protection-S5LV0487Po_19870513_HOL_238 [accessed 31 October 2011].

Hansard (1996) Overseas Development Administration. Lords Sitting, 7 February 1996. Http://hansard.millbanksystems.com/lords/1996/ feb/o7/overseas-development-administration [accessed 31 October 2011].

Hansard (2001) Animal Conservation Schemes. Written Answers 9 July 2001. Http://www.publications.parliament.uk/pa/cm200102/ cmhansrd/voo10709/text/10709w04.htm [accessed 30 October 2011].

Hansard (2004) Wildlife Management. Written Answers 1 April 2004. Http://hansard.millbanksystems.com/written_answers/2004/apr/ 01/wildlife-management-column_1563w [accessed 30 October 2011].

Hansard (2005) Palm Oil. Written Answers 14 November 2005. Http:// www.publications.parliament.uk/pa/cm200506/cmhansrd/ vo051114/text/51114W02.htm [accessed 30 October 2011].

HM Treasury (2000) Comprehensive Spending Review 200o. Http:// archive.treasury.gov.uk/sr200o/sr_econ.html [accessed 6 November 2011].

IIED (International Institute for Environment and Development) (1994) Whose Eden? An Overview of Community Approaches to Wildlife Management. International Institute for Environment and Development, London, UK.

IISD (International Institute for Sustainable Development) (2003) A summary report from 'Biodiversity after Johannesburg'. Sustainable Developments, 81(1), 1-7. Http://www. equatorinitiative.org/images/stories/News/ iisd_rpt_on_london_bdmdg03-05-03.pdf [accessed 2 October 2012].

itAD (Information, Training and Agricultural Development) (2001) Sustainable Agriculture Evaluation. Kenya Country Report. Webarchive.nationalarchives.gov.uk/+/http:// www.dfid.gov.uk/foi/dc/18apro2_sust_agri_kenya.pdf [accessed 10 October 2011].

IUCN, UNEP \& WWF (1980) World Conservation Strategy: Living Resource Conservation for Sustainable Development. IUCN, Gland, Switzerland.

Killick, T. (2005) Policy autonomy and the history of British aid to Africa. Development Policy Review, 23, 665-681.

KozIEll, I. (2001) Diversity not Adversity: Sustaining Livelihoods with Biodiversity. International Institute for Environment and Development, London, UK.

KozIELL, I. \& SAUNDERS, J. (eds) (2001) Living off Biodiversity. International Institute for Environment and Development, London, UK.

Lapham, N. \& Livermore, R. (2003) Striking a Balance: Ensuring Conservation's Place on the International Biodiversity Assistance Agenda. Conservation International, Washington, DC, USA.

Maxwell, S. (1999) The Meaning and Measurement of Poverty. Poverty Briefing No. 3. Overseas Development Institute, London, UK. 
Miller, D.C., Agrawal, A. \& Roberts, J.T. (2010) Explaining the Allocation of Foreign Aid for Biodiversity Conservation. Paper presented at the conference 'Aid Transparency and Development Finance: Lessons and Insights from AidData', University College, Oxford, UK, 22-25 March 2010. Http://s3.amazonaws.com/aiddata/ Miller_aiddata.pdf [accessed 29 February 2012].

NaO (National Audit Office) (1992) Overseas Aid: Water and the Environment. Her Majesty's Stationery Office, London, UK.

NaO (National Audit Office) (2010) The Work of the Department for International Development in 2009-10 and its Priorities for Reform. Her Majesty's Stationery Office, London, UK.

National Archives (2004) International Development Act. Snapshot taken on 02/08/2004. Http://webarchive.nationalarchives. gov.uk/+/http://www.dfid.gov.uk/policieandpriorities/ida/ ida_main.htm [accessed 24 October 2011].

OAtes, J. (1999) Myth and Reality in the Rainforest: How Conservation Strategies are Failing in West Africa. University of California Press, Berkeley, USA.

OdA (Overseas Development Administration) (1989) Manual of Environmental Appraisal. Overseas Development Administration, London, UK.

OdA (Overseas Development Administration) (1996) African Wildlife Policy Consultation: Final Report of the Consultation. Overseas Development Administration, London, UK.

ODi (Overseas Development Institute) (1975) More Help for the Poorest: A Comment on the White Paper. Http://www.odi.org.uk/ resources/docs/6598.pdf [accessed 24 October 2011].

ODi (Overseas Development Institute) (2003) Rural Development Forestry Network (RDFN) 1985-2003. Http://www.odi. org.uk/work/projects/details.asp?id=1267\&title=ruraldevelopment-forestry-network-rdfn [accessed 24 October 2011].

OECD (Organization for Economic Cooperation and Development) (1996) Shaping the 21st Century: The Contribution of Development Cooperation. Organization for Economic Cooperation and Development, Paris, France.

OECD (Organization for Economic Cooperation and Development) (2008) Statistics on Biodiversity-Related Aid. Http://www.oecd.org/dataoecd/26/24/40756129.pdf [accessed 29 February 2012].

Oksanen, T., Heering, M. \& Cabarle, B. (1993) A Study on Coordination in Sustainable Forestry Development. Unpublished Report to the TFAP Forest Advisors Group.

Phillips, J. \& Vaughan, K. (2006) A BOND Development and Environment Group Response to the UK Department for International Development White Paper 2006: 'Eliminating World Poverty: Making Governance Work for the Poor'. Http://www.bond. org.uk/pages/development-and-environment-group-news.html [accessed 2 March 2012].

Roe, D. (2008) The origins and evolution of the conservation-poverty debate: a review of key literature, events and policy processes. Oryx, 42, 491-503.

Roe, D. (2010) Whither biodiversity in development? The integration of biodiversity in international and national poverty reduction policy. Biodiversity, 11, 13-18.

Roe, D. \& Elliott, J. (2004) Meeting the MDGs: is conservation relevant? In The Millennium Development Goals and Conservation: Managing Nature's Wealth for Society's Health (ed. D. Roe), pp. 7-19. International Institute for Environment and Development, London, UK.

Sachs, J.D., Baillie, J., Sutherland, W.J., Armsworth, P.R., Ash, N., Beddington, J. et al. (2009) Biodiversity conservation and the Millennium Development Goals. Science, $325,1502-1503$.
Sanderson, S. (2005) Poverty and conservation: the new century's peasant question. World Development, 33, 323-332.

Sanderson, S. \& Redford, K. (2003) Contested relationships between biodiversity conservation and poverty alleviation. Oryx, 37, 1-2.

Satterthwaite, D. (2003) The Millennium Development Goals and Local Processes: Hitting the Target or Missing the Point? International Institute for Environment and Development, London, UK.

SAyers, J. \& Wells, M.P. (2004) The pathology of projects. In Getting Biodiversity Projects to Work: Towards More Effective Conservation and Development (eds T.O. McShane \& M. Wells), pp. 35-48. Columbia University Press, New York, USA.

Short, C. (2002) Bushmeat and Poverty. Speech to the UK Bushmeat Campaign Conference, Zoological Society of London, 28 May 2002. UK Department for International Development, London, UK. Http://www.dfid.gov.uk/pubs/files/bushmeat-speech-sos.pdf [accessed 5 November 2011].

Short, C. (2003) Address by the Rt Honourable Clare Short. Biodiversity after Johannesburg Conference, 3-4 March 2003, Zoological Society of London, London, UK. Http://www. equatorinitiative.org/index.php?option=com_content\&view= article $\&$ id $=405 \% 3$ Abajam $\&$ catid $=93 \% 3$ A2003-events $\&$ Itemid $=792$ [accessed 17 October 2011].

Smith, S., Bass, S. \& Craeynest, L. (2008) Curbing UK Impacts on Global Biodiversity: An Agenda for Action. International Institute for Environment and Development, London, UK.

Stiglitz, J. (1998) Towards a New Paradigm for Development: Strategies, Policies, and Processes. 1998 Prebisch Lecture. UNCTAD, Geneva, Switzerland.

TEEB (The Economics of Ecosystems and Biodiversity) (2010) The Economics of Ecosystems and Biodiversity: Mainstreaming the Economics of Nature: A Synthesis of the Approach, Conclusions and Recommendations of TEEB. UN Environment Programme, Nairobi, Kenya.

UK Parliament (undated a) Hansard 1803-2005. Http://hansard. millbanksystems.com/ [accessed 30 October 2011].

UK Parliament (undated b) Hansard. Http://www.parliament.uk/ business/publications/hansard/ [accessed 30 October 2011].

United Nations (2002a) Johannesburg Declaration on Sustainable Development. UN Department of Economic and Social Affairs, New York, USA.

United Nations (2002b) Johannesburg Plan of Implementation. UN Department of Economic and Social Affairs, New York, USA.

USAID (United States Agency for International Development) (2005) Biodiversity Conservation: A Guide for USAID Staff and Partners. United States Agency for International Development, Washington, DC, USA.

VEREKER, J. (2002) Blazing the trail: eight years of change in handling international development. Development Policy Review, 20, 133-140.

Warrener, D. (2004) Current Thinking in the UK on General Budget Support. Synthesis Paper 4. Overseas Development Institute, London, UK. Http://www.odi.org.uk/resources/docs/3723.pdf [accessed 28 February 2012].

\section{Biographical sketch}

Dilys RoE is a senior researcher at the International Institute for Environment and Development (IIED). Her research focuses on the linkages between biodiversity conservation and poverty alleviation and she coordinates IIED's Poverty and Conservation Learning Group (http://www.povertyandconservation.info). 